\title{
Waldemar Linke CP, Literacka ojczyzna Tobiasza. Tło kulturowe Tb jako klucz teologicznej lektury księgi, Wydawnictwo Verbinum, Warszawa 2013, 676 s. (Lingua Sacra. Monografie, 2)
}

\author{
Tomasz Maria Dąbek OSB \\ Uniwersytet Papieski Jana Pawła II w Krakowie \\ tomasz.dabek@upjp2.edu.pl (D) https://orcid.org/0000-0003-1427-0135
}

Rozprawa o. Waldemara Linke CP jest gruntownym studium opartym na oryginalnych tekstach Księgi Tobiasza w różnych wersjach greckich, aramejskich i hebrajskich, z uwzględnieniem przekładów łacińskich i w razie potrzeby także innych.

W obszernym wstępie (od. s. 11) autor przedstawia stan badań nad Księgą Tobiasza, zagadnienia związane z jej tłem kulturowym i czasem powstania oraz określa cel i metodę stosowaną w pracy.

Pierwsza część rozprawy omawia życie społeczne w Księdza Tobiasza. Rozdział pierwszy (od s. 53) ukazuje małżeństwo i rodzinę jako podstawowe instytucje wychowawcze, ekonomiczne, społeczne, narodowe i religijne w Tb. Autor charakteryzuje sposób zawierana małżeństw, związek małżeństwa z prawem spadkowym, cel pożycia małżeńskiego, endogamię jako zasadę małżeństw Izraelitów w diasporze oraz życie pary małżeńskiej. Analizuje cechy i cel rodziny - jej antropocentryzm (przewagę linii męskiej), zależność syna od ojca, wartość i sytuację dzieci oraz wnuków, dynamikę zależności w rodzinie, więzy w dalszej rodzinie i jej zakres oraz wspólnotę rodową. Rozdział kończy pokazanie teologicznego waloru tematu rodziny w Księdze Tobiasza oraz intertekstualna lektura Ps 128 (127) i Tb. Badania podsumowują trafne wnioski uwzględniające bogactwo złożonego problemu.

Drugi rozdział (od s. 139) mówi o pieniądzach, instytucjach finansowych i pracy w Księdze Tobiasza. W związku z pieniędzmi, handlem i usługami finansowymi przedstawia środki płatnicze, handel i wymianę handlową, usługi finansowe, karawany i podróże oraz względną wartość pieniądza. Omawia też przedstawione w księdze rodzaje pracy (przędzenie i tkactwo, rolnictwo) oraz wynagrodzenia, a także czynniki ekonomiczne w aparacie państwowym. Podsumowuje sformułowaniem wniosków. 
Druga część pracy poświęcona jest życiu religijnemu w Księdze Tobiasza. Najobszerniejszy trzeci rozdział (od s. 223) nosi tytuł: Religia i teologia $w$ Tb. Zawiera omówienie idei teologicznych w księdze: obraz, imiona i atrybuty Boga, prawo i przymierze, opatrzność, wszechwiedza Boga i przeznaczenie, eschatologia w Tb (Eschatologia wspólnotowa oraz indywidualna), kult publiczny i liturgia (świątynia, wspólnota kultu). Kończy się podsumowującymi wnioskami.

Rozdział czwarty (od s. 391) przedstawia prywatne praktyki pobożności i religijności w Księdze Tobiasza: modlitwę (jako prośbę, wyznawanie i błogosławieństwo), jałmużnę, normy czystości (dotyczące czystości pokarmów oraz obmyć) omawia rolę psa w Księdze Tobiasza wobec zagadnienia czystości oraz rolę ryby w Księdze.

Ostatni piąty rozdział (od s. 469) poświęcony jest angelologii i demonologii w Księdze Tobiasza. Autor rozpoczyna go zwróceniem uwagi na nową „falę anielską” w dzisiejszej kulturze oraz miejsce anioła we współczesnej teologii. Omawia demonologię w kulturach i religiach Bliskiego Wschodu (badania nad demonologią i pojęcie demona, demonologię Mezopotamii oraz perską), angelologię i demonologię w judaizmie (w pismach apokaliptycznych i w Biblii). Przedstawia role anioła i demona w Tb (omawia badania i dyskusje nad angelologią i demonologią $\mathrm{w}$ Tb, terminologię angelologiczną i demonologiczną w różnych wersjach językowych Tb, rolę postaci anioła w narracji i teologii Tb oraz demona w narracji i teologii Tb). Ukazuje Rafała jako uzdrowiciela i charakter wybawienia w Tb oraz inne funkcje Rafała. We wnioskach syntetycznie przedstawia genezę i specyfikę angelologii i demonologii w $\mathrm{Tb}$.

W zakończeniu (od s. 573) podsumowuje wyniki sumiennie przeprowadzonych badań. Obszerna bibliografia pokazuje doskonałą znajomość literatury badanych problemów w wielu językach. Podsumowanie w języku angielskim pozwala zorientować się $\mathrm{w}$ treści rozprawy i kierunkach podjętych badań osobom nie znającym języka polskiego.

Autor bardzo dobrze zna języki biblijne oraz wiele nowożytnych, co pozwala mu swobodnie korzystać z bogatej literatury. Niezwykle sumiennie analizuje problemy, szczegółowo porównuje różne wersje tekstów, pokazując stojące u ich podstaw nastawienie autorów, tłumaczy i redaktorów dzieła, w którym rodzina Tobiadów stojąca w opozycji do sadokickiego kapłaństwa i niektórych zasad reformy Nehemiasza pokazuje swą postawę jako gorliwych Izraelitów pragnących trwać wiernie w religii pierwszego przymierza. Imponująca bibliografia (od s. 590) obejmuje około 80 stron i zawiera bardzie 
wiele pozycji w różnych językach. To zestawienie jest zarówno świadectwem erudycji autora, jak i cenną pomocą dla zainteresowanych naukowym badaniem omawianych w rozprawie zagadnień.

Odpowiadając na pytanie zawarte $\mathrm{w}$ tytule i podtytule pracy, autor stwierdza w zakończeniu: „Jaka więc jest «literacka ojczyzna Tobiasza»? Odpowiedzieć należy, że jest nią tęsknota za świątynią, za wspólnotą religijną. Nie doczekała się ona właściwie innego śladu niż Tb, ale ten, który pozostał, do dziś działa na czytelników przez żywość opowiadania, barwność portretów ludzkich, mądrość przysłów i żar poetycki poezji modlitewnej. Wychwalanie Boga, które zajmuje naczelne miejsce wśród form religijności, o których mówi ta księga, nie wymaga świątyni i nie zależy od politycznych kompromisów i koncesji. Tobiadzi żyją więc w swej ojczyźnie świadomi, że ich prawość nie zostanie zapomniana przed Bogiem”.

Praca pokazuje wysoki poziom naukowy autora, pozwala lepiej zrozumieć wiele problemów związanych z życiem Izraelitów w Palestynie i w diasporze w okresie wygnania i po powrocie do czasów machabejskich. Jest interesującą lekturą zarówno dla biblistów, historyków, historyków religii, jak też dla wszystkich zainteresowanych głębszych zrozumieniem Pisma Świętego. 